\title{
Panamá, de Balboa a Bolívar: una construcción nacional entre hispanismo y panamericanismo
}

\author{
Panama, from Balboa to Bolívar: \\ National Construction between \\ Hispanicism and Pan-Americanism
}

\author{
David Marcilhacy* \\ (D) https://orcid.org/0000-0002-5874-1659 \\ Sorbonne Université/CRIMIC, Francia \\ david.marcilhacy@sorbonne-universite.fr
}

Resumen: Centrándonos en las políticas de la memoria implementadas por la república de Panamá en sus primeras décadas de existencia, nos proponemos confrontar dos centenarios que concentraron los esfuerzos de las autoridades en materia de política nacionalizadora y de diplomacia cultural: por un lado, el cuarto centenario del Descubrimiento del Mar del Sur por Vasco Núñez de Balboa, celebrado en Panamá entre 1913 y 1916; por otro, el centenario del Congreso Anfictiónico reunido por Bolívar en el istmo en 1826. Dichas conmemoraciones fueron organizadas por la elite liberal panameña en un doble contexto de especial tensión: por un lado, la crisis económica provocada por

* Agradezco a Marcela García Sebastiani, Aimer Granados, Clara E. Lida, Javier Moreno Luzón, Tomás Pérez Vejo y Miguel Rodríguez su ayuda. Este artículo se integra en el proyecto de investigación I+D+I HAR 2016-75002-P del Ministerio de Economía, Industria y Competitividad.

cómo citar: Marcilhacy, D. (2019). Panamá, de Balboa a Bolívar: una construcción nacional entre hispanismo y panamericanismo. Secuencia (105), e1605. DoI: https://doi.org/10.18234/secuencia.v0i105.1605

cc $(1)$ Esta obra está protegida bajo una Licencia Creative Commons Atribución-NoComercial 4.0 Internacional. 
la primera guerra mundial y que degeneró en una grave crisis social a mediados de los años veinte; por otro, su voluntad de renegociar el Tratado de 1903, para obtener de Estados Unidos condiciones más satisfactorias para la concesión del canal interoceánico. Basándonos en fuentes archivísticas, hemerográficas y en la ensayística, nos interesaremos por las ambigüedades que marcaron sendos proyectos, los cuales pretendían escenificar a una república encaminada en la vía del progreso y la modernidad, ocultando la trastienda de una sociedad fragmentada y una nación intervenida.

Palabras clave: conmemoraciones; nacionalismo; canal interoceánico; huelga inquilinaria; Tratado Kellogg-Alfaro.

Abstract: Focusing on the policies of memory implemented by the Republic of Panama in the early decades of its existence, we propose to compare two centenaries that concentrate the authorities' efforts in nationalization policy and cultural diplomacy. On one hand is the fourth centenary of the Discovery of the South Sea by Balboa, celebrated in Panama between 1913 and 1916; and on the other hand the centenary of the Amphycitonic Congress held by Bolívar in the isthmus in 1826. These commemorations were organized by the Panamanian liberal elite in a double context of particular tension: first, the economic crisis caused by the World War, which degenerated into a severe social crisis in the mid-1920s, and second, their aim to renegotiate the 1903 Treaty, to obtain more satisfactory conditions from the United States for the concession of the inter-oceanic canal. On the basis of archives, newspapers and essays, we study the ambiguities that marked both projects, which sought to present a Republic guided by progress and modernity to mask the reality of a fragmented society and a nation that had been intervened.

Key words: commemorations; nationalism; inter-oceanic canal; tenant strike; Kellogg-Alfaro Treaty.

Fecha de recepción: 11 de abril de 2018 Fecha de aceptación: 1 de enero de 2019 
E n materia de construcción de identidades e imaginarios, el caso de la República de Panamá adquiere un valor muy particular en el conjunto iberoamericano. Primero porque Panamá se constituyó muy tardíamente como país independiente (1903). Pero también porque su acceso a la independencia se realizó mediante la imposición de una tutela estadunidense que limitaba el uso de su soberanía. Panamá, así, entró en el concierto internacional como una nación intervenida, tanto por la cesión de la franja de tierra llamada "Zona del Canal" -según estipulaba el Tratado Hay-Bunau Varilla-, como por la disolución forzosa del ejército nacional en 1904 y la humillante imposición del artículo 136 en la Constitución del mismo año. ${ }^{1}$ El contexto en que se separó de Colombia fue interpretado como una afrenta por la mayoría de las repúblicas latinoamericanas. Dicha secesión auspiciada y apoyada por la potencia del Norte fue identificada como una forma de "pecado original" que por mucho tiempo ha pesado en la valoración de esta república a nivel internacional.

Por eso mismo, la República de Panamá constituye un observatorio privilegiado para analizar las estrategias desplegadas por las elites que presidieron el nacimiento de ese joven Estado para dotarse de un relato nacional legitimador y construir su imagen en el exterior. Su proceso tardío de construcción como Estado-nación fue complejo, dadas las contradicciones que recorrían la sociedad panameña de principios del siglo y por la situación de dependencia que caracterizaba a Panamá (Araúz y Pizzurno, 1996; McCullough, 2012; McGuinness, 2009). La historia del istmo centroamericano está estrechamente unida al proceso globalizador, siendo el objeto constante de rivalidades de las grandes potencias desde el siglo XVI (Castillero Calvo, 1999, pp. 41-70). Por la posición geoestratégica muy especial que ocupa, el istmo interoceánico representa la encrucijada y el puente de las Américas, que estaba destinado a volverse, según la fórmula de Bolívar, el "corazón del universo". ${ }^{2}$

Hasta una época reciente, gran parte de la historiografía producida sobre el Panamá republicano se había concentrado en rastrear la construcción nacional desde un enfoque nacionalista, o antiimperialista, centrándose en la relación problemática tanto con Colombia como con Estados Unidos. Sin

${ }^{1}$ A semejanza de la Enmienda Platt integrada en la Constitución cubana de 1901, el artículo 136 de la Constitución panameña de 1904 estipulaba el derecho para el gobierno de Estados Unidos a intervenir en cualquier punto de la República de Panamá para restablecer la paz pública y el orden constitucional.

2 "Discurso pronunciado ante el Congreso de Angostura" (1819) en Bolívar (2004, p. 67). 
embargo, desde la perspectiva constructivista de autores como Gellner, Anderson y Hobsbawm, puede considerarse la nación como el producto de un proceso complejo y dinámico situado históricamente y basado en las interacciones de distintos actores movidos por estrategias de interés y adaptación a un entorno cambiante. Las imágenes que generan estos agentes -elites, gobernantes, estructuras estatales, pero también asociaciones y sociedad civilvan conformando una identidad colectiva, una conciencia diferenciadora de la nación y un sentimiento de lealtad a la misma. Como lo recalca Anne-Marie Thiesse (2006), también resulta fundamental estudiar el papel de lo transnacional en estos procesos de nacionalización. Algunos trabajos punteros así han subrayado el papel del hispanismo en la construcción nacional panameña (Chirú Barrios, 2011; Pizzurno, 2011; Szok, 2001). No obstante, dichos estudios no centran su reflexión en la funcionalidad en materia de política exterior de estos referentes externos -no sólo el hispanismo, sino también el latinoamericanismo y el panamericanismo.

Exposiciones, centenarios y referentes icónicos de la memoria colectiva: a partir de estos temas tratados por la historia cultural, aplicada a las relaciones internacionales, se ofrecerá aquí una reflexión sobre las paradojas de la construcción nacional de Panamá, un país nacido para ponerse al servicio del mundo (como reza su divisa nacional Pro Mundi Beneficio), cuya identidad propia y trayectoria exitosa buscaron afirmar sus elites para legitimar su acción desde 1903, en el marco de una relación asimétrica con el protector estadunidense. Apoyándose en un análisis comparativo, este estudio se enfocará en dos iniciativas de envergadura en materia de políticas de la memoria y de diplomacia cultural: por un lado, la celebración del cuarto centenario del descubrimiento del Pacífico (1913) y la exposición nacional que le siguió (1916); por otro, el congreso conmemorativo que organizó la república panameña en 1926, un siglo después de que Bolívar reuniera allí el famoso Congreso Anfictiónico. Para entender su alcance, conviene vincular esos proyectos con los dos objetivos principales de la política exterior panameña de las décadas 1910 y 1920: mejorar las condiciones de la relación bilateral con Estados Unidos, y consolidar su proyección internacional para obtener un lugar en el concierto de las naciones. De hecho, ambas conmemoraciones intervinieron en momentos en que la diplomacia panameña intentaba renegociar el Tratado Hay-Bunau Varilla de 1903 para obtener condiciones más satisfactorias en la concesión del canal interoceánico. Si bien en 1915 la iniciativa pronto 
naufragó debido a la contienda mundial, ${ }^{3}$ en 1926 el "Congreso Bolivariano"4 coincidió con el segundo intento panameño, que desembocaría ese mismo año en el Tratado Kellogg-Alfaro, nunca ratificado.

Basándonos en fuentes oficiales (legislación, archivos diplomáticos, discursos reproducidos) y en la publicística producida en Panamá y en España en ocasión de ambos aniversarios, veremos de qué manera las autoridades y elites panameñas se valieron de ambos centenarios (1913 y 1926) como estrategia para promover un modelo de nación afín a sus intereses y recabar apoyos en el concierto internacional para salir de un diálogo desequilibrado con Estados Unidos. Analizaremos cómo dichos certámenes no sólo constituyeron una campaña de imagen dirigida hacia fuera, sino que también pretendieron crear un imaginario colectivo, destinado a responder a los desafíos planteados por una cohesión nacional que, en estos años, se mostraba frágil y deficiente.

\section{PANAMÁ Y SU ESTRATEGIA DE IMAGEN INTERNACIONAL}

Desde su constitución como república independiente, Panamá tuvo que luchar no sólo por obtener la normalización de sus relaciones exteriores, sino también por corregir la imagen negativa generalmente asociada con su nombre. Si bien el reconocimiento de la nueva república se benefició del apoyo de grandes potencias como Estados Unidos y Francia y quedó asegurado en las distintas cancillerías entre fines de 1903 y los primeros meses de 1904 (Araúz, 1994, vol. 1, pp. 145 y ss.), la tarea de corregir la percepción que se tenía de la república recién constituida fue más larga. Dichos prejuicios, muy frecuentes en la publicística de la época, se explican por las condiciones en que la República de Panamá se separó de Colombia, en noviembre de 1903: a ojos de la mayoría de los comentaristas latinoamericanos, dicho acceso a la independencia no sólo resultó dañino para la soberanía de una república hermana, sino que constituyó tras el 98 una nueva manifestación del expansionismo

${ }^{3}$ En 1915, durante su primer mandato presidencial, Belisario Porras redactó junto con Eusebio A. Morales, su representante en Washington, un nuevo tratado para presentarlo a la consideración de Estados Unidos.

4 Esa era su designación más común, pero su nombre oficial era el de "Congreso Panamericano Conmemorativo del Congreso de Bolívar". 
estadunidense en el Caribe, tendencia calificada de imperialismo absorbente. La creciente hegemonía de Estados Unidos en esa región y el control de los puntos estratégicos del istmo centroamericano entraban en los planes de los estrategas del poder naval estadunidense, una noción teorizada por Alfred T. Mahan. Así, la separación de Panamá se leyó como un paso determinante en la afirmación de la supremacía estadunidense sobre el Caribe y el Golfo de México, convertidos en un "Mare Nostrum" norteamericano y en puerta de entrada al Pacífico y sus rutas marítimas.

Es más, el caso de la secesión panameña ilustraba una forma de colusión con los intereses financieros estadunidenses y franceses, vinculados a la banca y a los inversionistas de la compañía del canal, quienes financiaron el movimiento secesionista y condicionaron su éxito (McCullough, 2012, pp. 243-266). La gesta independentista -elemento fundamental de los relatos nacionales americanos- nació con una mancha original: si bien a nivel oficial las reacciones fueron más precavidas, la interpretación que se hizo de ella en la prensa y la ensayística del continente latinoamericano tendió a adoptar sin muchos matices la perspectiva colombiana, siendo denunciada la separación como el "rapto" o el "despojo" de Panamá (Núñez, 2004). El auto de acusación venía de los propios Estados Unidos, a raíz de una investigación que hizo el magnate del periodismo Joseph Pulitzer, director del influyente diario neoyorquino The World, quien acusó al presidente Roosevelt de haber fomentado la secesión a base de intereses financieros y de sobornos (United States Congress House, 1913). Este relato naturalmente increpaba a los abogados y banqueros que, como Nelson Cromwell, habrían urdido la conjura, sino también de manera implícita a los próceres de la independencia, quienes no dudaron en dejar en manos del francés Philippe Bunau-Varilla la representación plenipotenciaria de la nueva república para negociar en Washington el tratado de concesión canalera, que de inmediato se reveló ser muy perjudicial para el joven Estado. ${ }^{5}$ Desde entonces se creó una suerte de "leyenda negra" de la independencia panameña, que parte de la historiografía nacional y extranjera ha resumido con frases como "Panama made in USA" o "el país creado por Wall Street” (Araúz, 2004; Díaz Ospino, 2004).

${ }^{5}$ El Tratado Hay-Bunau Varilla fue firmado en Washington el 18 de noviembre de 1903, a las dos semanas de consumarse la independencia, sin que las autoridades panameñas pudieran enmendar el texto negociado por Bunau Varilla. 
Como enseñan las notas del archivo diplomático panameño, el buen nombre de Panamá también resultaba perjudicado por otra asociación que en el lenguaje común de la época asimilaba el nombre de Panamá con la idea de corrupción, de estafa o de engaño. ${ }^{6}$ Esto se debía a la enorme repercusión mediática que a escala mundial había producido el "escándalo de Panamá" ocasionado por la quiebra de la compañía francesa del canal en 1889. Desde aquel caso de corrupción, que arruinó a cientos de miles de pequeños suscriptores e hizo temblar los cimientos de la Tercera República francesa, la expresión "un Panamá" quedaba asociada en el lenguaje común francés y en el imaginario colectivo como sinónimo de corruptela, avaricia y descalabro... imágenes sin duda perjudiciales para una república que acababa de independizarse para encaminarse en la senda de la modernidad y que esperaba atraer a los inversionistas extranjeros.

De ahí que muy tempranamente las autoridades panameñas emprendieran campañas de carácter cultural y diplomático para crear un discurso nacionalizador positivo de consumo interno y para enderezar la percepción exterior que se tenía del país. Esta estrategia de imagen tenía otro objetivo no menos importante, o sea superar el relativo aislamiento en el que se encontraba Panamá respecto de sus vecinos centro y sudamericanos, dada la prioridad otorgada a la relación con Estados Unidos en todos los ámbitos. A partir de ahí, las autoridades panameñas desplegaron distintas iniciativas para mejorar la imagen de su país e insertarlo como miembro de pleno derecho en la comunidad internacional. Sin duda, el mayor intento en términos de expectativas, de esfuerzo colectivo y de inversión pública fue la Exposición Nacional de Panamá, calcada sobre el modelo de las grandes exposiciones universales entonces en boga. Dicha exposición, inicialmente proyectada para el año 1913, debía coincidir con una doble coyuntura que le daría el lustre internacional esperado: el cuarto centenario del descubrimiento del Pacífico y la próxima inauguración del canal interoceánico (Chirú Barrios, 2011, pp. 82-100; Marcilhacy, 2006, pp. 600-614; Samos, 2017).

${ }^{6}$ Véase, por ejemplo: Comunicaciones sobre el uso despectivo en la prensa de la palabra Panamá. Legación de Panamá en México. Vol. 1, 1923-1935, exp. 45. Archivo del Ministerio de Relaciones Exteriores de Panamá (en adelante AMIREP), Panamá. 


\section{LA NACIÓN INTEROCEÁNICA EN BUSCA DE SUS RAÍCES: EL IV CENTENARIO DEL DESCUBRIMIENTO DEL MAR DEL SUR (1913) Y LA EXPOSICIÓN NACIONAL DE 1916}

Desde su origen, este proyecto conmemorativo tuvo un marcado carácter hispanista y se proyectó conjuntamente con las máximas autoridades españolas. Para la pequeña elite panameña encargada de los destinos de la nación, celebrar a Vasco Núñez de Balboa, a quien la memoria colectiva consideraba el "descubridor del Pacífico" permitía destacar la remota vocación del istmo como encrucijada dedicada al comercio, revelada por el conquistador castellano. Conmemorar aquel hito histórico no sólo correspondía con el modelo de nación que dichas elites criollas querían promover, una nación a su imagen -blanca, hispanohablante, de antigua alcurnia-, sino que permitía legitimar su acción a la cabeza del país: recuperar la figura de Núñez de Balboa permitía reanudar con el imaginario de una nación interoceánica que hoy como antaño seguía pionera en la senda del progreso, gracias a la acción de sus clarividentes dirigentes, émulos de los audaces conquistadores del siglo XVI.

La idea de celebrar el centenario de 1913 circulaba desde el año de 1906, cuando el académico de la historia Ángel de Altolaguirre sugirió que las autoridades españolas y la Real Sociedad Geográfica invitaran a todas las naciones ribereñas del Pacífico a celebrar conjuntamente la hazaña del conquistador Núñez de Balboa, descubridor del Mar del Sur, a quien el académico considerada "una gloria puramente española". ${ }^{7}$ Esta iniciativa se inscribía en la política de conmemoraciones americanistas que desde 1892 había iniciado España como parte de su programa de atracción dirigido hacia las repúblicas hispanoamericanas (Marcilhacy, 2010, pp. 330 y ss). En 1912, el recién elegido presidente de Panamá, el liberal Belisario Porras, hizo suyo el proyecto e hizo adoptar una ley que declaraba festivo el 25 de septiembre de 1913 y que ordenaba conmemorar "la hazaña del adelantado Vasco Núñez de Balboa" con una exposición nacional, a la que la "antigua madre Patria" sería invitada especialmente, junto con los países hermanos del continente americano. ${ }^{8}$ Para Porras, se trataba de marcar simbólicamente una nueva era política. La

7 Ángel de Altolaguirre, "Una proposición”, El Imparcial, 24 de septiembre de 1906, reproducido en Cultura Hispano-Americana, Madrid, abril de 1913, pp. 17-20.

${ }^{8}$ Ley 42 del 13 de diciembre de 1912. Gaceta Oficial de Panamá, 19 de diciembre de 1912, p. 1. 
llegada al gobierno de los liberales desde 1910, que por dos décadas serían hegemónicos en la política istmeña, suponía el acceso al poder de la elite comercial y urbana, cuyo sustento dependía de la renta de tránsito, cuando los conservadores eran en su mayoría terratenientes. De ahí el marcado interés de los liberales en apoyar el relato de una nación dedicada al comercio y los intercambios desde sus orígenes.

Deseoso de dar lustre a su iniciativa, Porras dirigió al rey Alfonso XIII una carta autógrafa impregnada de los más vivos sentimientos hispanófilos en la que le participaba su decisión de celebrar el magno centenario. Haciendo una referencia implícita a las frustraciones de ambas naciones ante el creciente poderío de Estados Unidos en la región, dicha carta subrayaba la importancia de reforzar los vínculos de solidaridad entre pueblos de un mismo origen que compartían idénticas aspiraciones de cara al futuro:

Grande y buen amigo: Al tener el alto honor de dirigirnos a V. M. para someter a vuestra consideración una idea que liga a la Patria nuestra al nombre del pueblo hidalgo de que sois el más caracterizado representante, es motivo de viva satisfacción para nosotros ofreceros nuestro entusiasta y amistoso saludo, con la más sincera protesta de aprecio del pueblo y Gobierno panameños, para la noble Nación española y su ilustre Soberano. Entre las antiguas colonias españolas de América y la Metrópoli se han iniciado en los últimos años vigorosas corrientes de simpatía, que tienden a estrechar los vínculos de amor y solidaridad que deben cultivarse entre pueblos de un mismo origen, que hablan la misma lengua, y que por similitud de aspiraciones marchan por la misma ruta hacia las conquistas del porvenir. La República de Panamá acaba de dar una muestra de que participa de ese movimiento noble de acercamiento hacia España, y por medio de una ley, expedida por la Asamblea Nacional, ha decretado la glorificación del descubridor del mar del Sur en el IV centenario de aquel hecho histórico, que el genio ha brindado a las brillantes páginas del heroísmo de España. ${ }^{9}$

Esta iniciativa encontró inmediato apoyo en Alfonso XIII que, en marzo de 1913, adoptó un real decreto que anunciaba la organización de una

${ }^{9}$ Carta de Belisario Porras a S. M. el Rey. 31 de enero de 1913. Sección del Ministerio de Relaciones Exteriores. Leg. H 2575. Archivo Histórico Nacional de España (en adelante AHNE), Madrid, España. 
conmemoración oficial en España. ${ }^{10}$ En ambos casos, la implicación de las autoridades se debía tanto a la voluntad de convertir ese aniversario en un momento de exaltación nacional como al deseo de no dejarles el protagonismo a Estados Unidos: de hecho, desde 1910 la nación que se había hecho con las obras de construcción del canal interoceánico había anunciado su intención de celebrar el cuarto centenario del descubrimiento del Pacífico junto con la inauguración de aquella obra, mediante una portentosa exposición internacional en San Francisco (Moreno Luzón, 2017). Tanto para Panamá, expuesta a la presencia neocolonial del "protector" estadunidense en la Zona del Canal, como para España, marcada por la pérdida de su influencia en el Caribe desde 1898, era inconcebible dejar que los estadunidenses celebraran solos el magno evento.

Si bien en España la conmemoración fue ante todo científica, consistente en un ciclo de conferencias en la Real Sociedad Geográfica y la organización del Primer Congreso de Historia y Geografía Hispanoamericanas (que se reuniría en Sevilla en abril de 1914), ${ }^{11}$ el gobierno panameño le dio al proyecto toda la importancia que le permitían sus capacidades financieras todavía muy precarias. ${ }^{12}$ El centenario de 1913 entró de lleno en las políticas de la memoria promocionadas por la elite liberal para construirse una genealogía prestigiosa y compensar la imagen de una república inventada por Washington. Tal como se desprendió de la ceremonia de colocación de la primera piedra de la exposición, que tuvo lugar el 25 de septiembre, la narrativa nacionalista panameña tuvo a bien convertir a la figura de Núñez de Balboa en un mito fundacional (Chirú Barrios, 2012). Los discursos recalcaron no sólo el carácter heroico de Vasco Núñez de Balboa, el "intrépido" conquistador que había atravesado las selvas del Darién para luego tomar posesión del Mar del Sur, sino también su significación para el destino de Panamá: con su descubrimiento, Núñez de Balboa habría perfilado el destino geográfico de esta tierra como lugar de tránsito (Sociedad Española de Beneficencia, 1913). Esta identificación resultaba esencial para vertebrar el imaginario de la "nación

${ }^{10}$ Real Decreto del 26 de marzo de 1913. Gaceta de Madrid, 9 de abril de 1913.

${ }^{11}$ Vasco Núñez de Balboa y el descubrimiento del Mar del Sur (Océano Pacífico). Boletín de la Real Sociedad Geográfica, t. LV, 1913, pp. 409-432. Esta celebración se completaría con una ceremonia en la Casa de América de Barcelona, que sin embargo no tuvo el carácter oficial de los demás actos.

${ }^{12}$ La exigua anualidad de 250000 dólares prevista para la concesión canalera con Estados Unidos sólo empezó a ser abonada en 1913, conforme al Tratado de 1903, y la exención de impuestos para los comisariatos de la Zona del Canal suponía una grave pérdida para la Hacienda pública panameña (Kalmanovitz, 2015). 
interoceánica": permitía por un lado subrayar su importancia histórica en la configuración del imperio español -al constituir el nexo esencial en la ruta del oro entre el Perú y la Península ibérica-y, por otro, resaltar el actual valor estratégico del istmo como centro de los intercambios mundiales.

De ahí que tanto las autoridades españolas como los prohombres panameños reinterpretaran la hazaña de Núñez de Balboa en función del nuevo orden geopolítico que suponía la apertura del canal interoceánico por los ingenieros militares estadunidenses. De manera elocuente, el real decreto adoptado en España insistía en lo trascendental que representaba aquel descubrimiento "para el progreso humano", identificando a España como la auténtica inspiradora de aquel prodigio de la tecnología moderna. En definitiva, como pretendía demostrarlo una obra histórica publicada en 1915 bajo el sugestivo título Los precursores españoles del Canal Interoceánico (Pérez y Nougués, 1915), los verdaderos iniciadores del canal interoceánico no eran ni franceses ni estadunidenses, sino auténticos caballeros de la "raza" española, los conquistadores del siglo XVI (Marcilhacy, 2006, p. 611). Junto a la construcción peninsular del héroe español (Mena García, 2014), se procedió del otro lado del Atlántico a una "panameñización" de la figura de Núñez de Balboa, convertido en héroe nacional y Padre de la Patria. Y es que, desde los primeros años de la república, la figura de Balboa ocupó un lugar central entre los símbolos de este joven Estado-nación que había de inventarse una tradición: a la moneda oficial se le dio el nombre de Balboa, ${ }^{13}$ y su efigie apareció en los sellos postales y hasta, como muestra de nacionalismo banal, en la cerveza nacional "Balboa", producida desde 1910 por la Panama Brewing and Refrigeration Company. De este modo, Panamá parecía dar la espalda a los relatos hispanófobos que, en muchos puntos del continente, seguían rechazando a las figuras de los conquistadores, símbolos de crueldad y codicia, a pesar del cambio de discurso que en la materia habían introducido los primeros centenarios de las independencias... En aras de la modernidad, la república proyectada por esas elites parecía reconciliada con aquel pasado y sólo considerarlo como un feliz precedente en que el istmo había constituido el nexo central de un gran imperio.

Este fenómeno se integra en el contexto de difusión de la corriente hispanista, a semejanza de la recuperación de la raíz española que se expresó en otras repúblicas en torno a los centenarios de las independencias (Moreno Luzón, 2010; Pérez Vejo, 2011, pp. 171 y ss.). Para la República de Panamá,

${ }^{13}$ Ley 84 del 28 de junio de 1904. Gaceta Oficial de Panamá, 5 de julio de 1904, pp. 1-2. 
recuperar el legado hispánico debía servir a cimentar a la joven y variopinta nación, deshacerla de su imagen de "república negra" -por el aluvión de trabajadores afroantillanos- $y$ revestirla de referencias a un pasado prestigioso $y$ en consonancia con su pretensión de constituir el eje vertebrador del mundo americano. La figura de Vasco Núñez de Balboa reunía todo eso y podía constituir el vector privilegiado de este discurso simbólico. En el istmo, también era muy activa la colonia española, representada por asociaciones como la Delegación de la Unión Ibero-Americana, presidida por el cónsul Emilio de Motta, el Centro Español, dirigido por Bartolomé Bosch, o la Sociedad Española de Beneficencia, cuyo presidente honorario era el influyente empresario Gervasio García. Toda una red de diplomáticos, comerciantes, intelectuales e inmigrantes íntimamente vinculados con la elite europeizada panameña así constituyeron los agentes que aseguraron la impregnación de ese imaginario hispanista en la construcción nacional panameña.

La inauguración en 1924 del monumento a Vasco Núñez de Balboa, proyectado desde 1913 en el marco del centenario, fue otro ejemplo de ese discurso nacionalista de vindicación de la genealogía española. Planteado como símbolo de la unión de la "raza hispánica", el monumento debía ser financiado por suscripción de España junto con todas las repúblicas latinoamericanas. Si bien Alfonso XIII y Belisario Porras encabezaron dicha suscripción con sumas relevantes (50 000 pesetas cada uno), la comisión encargada de la obra tardó diez años en reunir los fondos... El estallido de la Gran Guerra paralizó completamente la iniciativa y a los pocos años surgieron tensiones entre el gobierno español, que supervisaba la recolección de los fondos, y el gobierno panameño, impaciente por ver realizarse la obra antes del turno presidencial. ${ }^{14}$

Fiel a su deseo de hacer de la matriz española el eje vertebrador de la nacionalidad, el presidente Porras encargó la realización de la obra a dos famosos escultores españoles, Mariano Benlliure y Miguel Blay, y solicitó al rey para inaugurar en persona el tan esperado monumento. ${ }^{15}$ Los argumentos cruzados por ambos servicios diplomáticos nos dan una indicación de cómo la estatuaria en tanto que instrumento de diplomacia cultural entraba en feroces

${ }^{14}$ Véanse los intercambios entre el ministro de Panamá en Madrid, Antonio Burgos, y el Ministerio de Estado español. Sección del Ministerio de Relaciones Exteriores. Leg. H 2575. AHNE, Madrid, España.

${ }^{15}$ Carta confidencial de Belisario Porras al Ministro español en Panamá, Conde de San Simón, en 26 de diciembre de 1923. Sección del Ministerio de Relaciones Exteriores. Leg. H 1674. AHNE, Madrid, España. 
batallas de memoria: en carta confidencial dirigida al Ministerio de Estado, el cónsul español en Panamá no dejaba de referirse al precedente de diciembre de 1923, cuando una misión diplomática francesa de muy alto nivel vino a bordo de un buque de guerra a inaugurar el imponente "Monumento a los franceses zapadores del Canal", para señalar que España debería corresponder con una misión de igual relieve. ${ }^{16}$ Advertencias que quedaron letra muerta, ya que el gobierno español, por motivos financieros, se limitó en mandar a su ministro plenipotenciario en Caracas, Ángel Ranero y Rivas. ${ }^{17}$

Con todo, la inauguración del monumento a Vasco Núñez de Balboa fue un acontecimiento fastuoso, y constituyó como una despedida al presidente Porras -patrocinador del proyecto-, que una semana después dejaría la sede presidencial a su delfín Rodolfo Chiari. Los festejos oficiales duraron del 25 al 29 de septiembre y reunieron a representantes de todos los países que habían contribuido a la obra. ${ }^{18}$ A todas luces los promotores de la ceremonia buscaron en esta ocasión resaltar el lugar prominente que tenía Panamá en el seno de la familia hispanoamericana, como un año antes habían demostrado la pertenencia de Panamá a la latinité, acogiendo con pompa a la comitiva francesa para inaugurar el monumento a De Lesseps y los obreros franceses. ${ }^{19}$

El 29 de septiembre de 1924, declarado día de júbilo nacional, fue desvelado el monumento ante un público estimado en unas 10000 personas. ${ }^{20} \mathrm{Co}$ locado en un pedestal encaramado por un globo terráqueo, expresión del destino geográfico de Panamá como corazón del mundo, el Balboa esculpido por Benlliure era triunfante y arrogante (Marcilhacy, 2006, p. 609; Moreno Luzón, 2017). Con la mirada dirigida hacia el mar, el Adelantado blandía una espada en forma de cruz, junto con el pendón de Castilla. Soldado y monje, conquista y evangelización, España y su imperio planetario, la obra lo resumía todo con

${ }^{16}$ Carta del Conde de San Simón en 15 de marzo de 1924. Sección del Ministerio de Relaciones Exteriores. Leg. H 1674. AHNE, Madrid, España.

${ }^{17}$ Inauguración del monumento a Balboa en Panamá. Legación de España en Panamá. $1^{\mathrm{a}}$ serie, vol. 5, exp. 32. AMIREP, Panamá.

${ }^{18}$ Remitimos al "Programa oficial", a la serie de recortes de prensa de la inauguración del Monumento a Balboa y al Despacho núm. 108 del 8 de octubre de 1924 al Presidente del Directorio Militar. Sección del Ministerio de Relaciones Exteriores. Leg. H 1674. AHNE, Madrid, España.

19 "Imponente y solemne ceremonia: los discursos del presidente y del comandante del 'Jeanne d'Arc”, La Estrella de Panamá, 5 de diciembre de 1923.

20 "Inauguración de la estatua a Vasco Núñez de Balboa", El Mundo, núm. 27, septiembre de 1924, p. 26, Panamá. Desde Panamá. Inauguración del monumento a Balboa. Unión Ibero-Americana, septiembre-octubre de 1924, pp. 18-19, Madrid. 
gran fuerza simbólica y afirmaba su función pedagógica. La tonalidad de los discursos confirmó la fábrica de Vasco Núñez de Balboa como héroe de "la raza" y la reivindicación de las glorias del pasado colonial como fragua de la nacionalidad y afirmación de orgullo. Así lo dijo Porras en su discurso:

¡Héroe! Aquí quedarás como una reparación y como un ejemplo, y como un modelo de tu raza. [...] Que sirvas aquí para recuerdo de la madre España, fecunda, que dio al mundo soldados de hierro, héroes sufridos, titanes que dominaban el mar y sus peligros, y las tierras desconocidas, y todos los endriagos que las habitaban; exploradores sin miedo, conquistadores invulnerables y colonizadores sabios. ${ }^{21}$

A muchos niveles se trataba de un discurso de compensación simbólica para un país sometido a la tutela estadunidense y que ni siquiera se beneficiaba del producto generado por el canal, que desde 1915 había alcanzado la rentabilidad.

Es más, el emplazamiento del mismo monumento debió cambiarse a petición del gobernador estadunidense. La intención inicial era colocar la estatua en la entrada del canal, "en sitio donde [fuera] saludada eternamente por las banderas de todas las naciones y por los hombres de todas las razas":22 así se pretendía erigir a Núñez de Balboa en perceptor simbólico de un tributo de homenaje de los buques del mundo entero que pasarían por delante, cuando Estados Unidos reclamaría por su parte un derecho de paso monetario. Pero las autoridades del canal se negaron a ello, oficialmente por motivos de seguridad, y hubo que colocar el monumento en una zona muy distante, el Barrio de la Exposición (Chirú Barrios, 2012). Se trataba de un ensanche nuevo, nacido de un proyecto urbanístico de gran alcance que se había planeado junto con el centenario de 1913. Pretendía dotar a la ciudad de una urbanización moderna que sirviera de vitrina del Panamá republicano y le ofreciera toda clase de comodidades, necesarias para convertir a la ciudad en capital y alojar a las legaciones extranjeras (Samos, 2017). Así el héroe Núñez de Balboa vino a parar en ese barrio nuevo, apartado tanto de Panamá Viejo

21 "Homenaje a la memoria de Vasco Núñez de Balboa. Un monumento en Panamá al esforzado descubridor del Pacífico", ABC, 7 de diciembre de 1924, p. 6.

${ }^{22}$ Carta de Belisario Porras a S. M. el Rey, en 31 de enero de 1913. Sección del Ministerio de Relaciones Exteriores. Leg. H 2575. AHNE, Madrid, España. 
como del casco colonial y del canal del que le decían precursor, pero -eso sí-a pocas cuadras del recién inaugurado monumento a Cervantes. El distrito se llamaba "de la Exposición" porque ocupaba los terrenos de la gran Exposición Nacional que había sido proyectada en el marco del mencionado centenario. ${ }^{23}$ Aquel gran proyecto nacional -la Exposición- debía situar a Panamá como centro del continente americano y como último llegado en la gran familia hispanoamericana, España incluida. Por eso el gobierno había invitado oficialmente a que participaran con sendos pabellones a Estados Unidos, todas las naciones latinoamericanas y España -como huésped especial-. ${ }^{24}$ Todos habían de congregarse en el istmo para celebrar ante los ojos del mundo aquel prodigio de la ingeniería moderna, que iba a revolucionar las comunicaciones mundiales y que era la realización del viejo sueño de los colonizadores españoles. Para una joven nación que apenas cumplía dos lustros de independencia, el propósito de la exposición de Panamá entraba directamente en su estrategia de imagen internacional: se trataba mediante la exposición de atraer a delegaciones y visitantes del mundo entero para mostrarles los logros conseguidos en materia de modernización y los potenciales que esta tierra ofrecía a los inversionistas (Scoullar, 1916-1917; The Latin American Publicity Bureau, 1916). También era una campaña para revestir de prestigio el nombre de Panamá y reivindicar un justo reconocimiento a su contribución al progreso de la humanidad por la obra del canal.

Sin embargo, la exposición resultó ser un semifracaso. Primero su inauguración corrió la misma suerte que el monumento a Vasco Núñez de Balboa: inicialmente prevista para enero de $1914,{ }^{25}$ tuvo que aplazarse seis veces hasta febrero de 1916, por las enormes dificultades financieras que debió enfrentar la Hacienda pública y que retrasaron la construcción de los pabellones. Luego la recepción no fue la esperada: se convirtió en una exposición reducida a lo mínimo en cuanto a la participación internacional, que quedó limitada a Estados Unidos y Cuba, el pabellón de España siendo inaugurado sólo después

${ }^{23}$ Expediente 474: Exposición Universal de Panamá con motivo del Centenario del Descubrimiento del Pacífico. Sección del Ministerio de Relaciones Exteriores, leg. H 3219, exp. 474. AHNE, Madrid, España.

${ }^{24}$ Participación de España en la Exposición de Panamá. Legación de Panamá en España. Vol. 2, 1915-1919, exp. 17. AMIREP, Panamá,

${ }^{25}$ Véase el reglamento: Secretaría de Fomento (1913). 
del certamen. ${ }^{26}$ Todos los demás países invitados desistieron de asistir o cancelaron su participación. Esta desafección se debió al estallido de la primera guerra mundial, pero también a la competencia que le hicieron las dos grandes exposiciones que se verificaron en el mismo momento en Estados Unidos: la Exposición Internacional Panamá-California de San Diego y la Exposición Internacional Panamá-Pacific de San Francisco, ambas inauguradas en 1915. El certamen de San Francisco le copó el protagonismo al evento panameño, y paradójicamente la conclusión de la obra del canal acabó celebrándose en California. La exposición de Panamá debía simbolizar la entrada de la nueva república en la modernidad, pero lo que más bien afirmó era la potencia comercial estadunidense, ya que la única sección que en su seno tuvo real éxito fue la muestra agrícola, comercial e industrial del potente vecino y protector. En resumidas cuentas, la Exposición Nacional no dio los resultados esperados y se interpretó más bien como una oportunidad perdida, dado la escasa repercusión mediática que tuvo fuera de las fronteras, el reducido número de visitantes y el endeudamiento que causó a las muy frágiles arcas públicas.

Tras ese relativo fracaso, las elites políticas y culturales panameñas tuvieron que esperar varios años antes de poder formular un nuevo proyecto que permitiera reunir en el istmo a numerosas delegaciones susceptibles de servir de agentes para difundir en el exterior una imagen favorable del país y de sus posibilidades. La oportunidad se presentó en 1926, al corresponder ese año con el Centenario del Congreso Anfictiónico que, en 1826, había reunido el libertador Simón Bolívar en el istmo centroamericano.

\section{EL CENTENARIO DE 1926, VITRINA DE PANAMÁ, TIERRA DE OPORTUNIDADES}

El centenario de 1926 se organizó en torno a tres manifestaciones que todas contenían una dimensión memorial: por un lado, un gran congreso conmemorativo internacional que revivió la histórica asamblea panamericana de 1826; por otro, la inauguración de un imponente monumento a Simón Bolívar en una céntrica plaza del casco viejo; $y$, por fin, una serie de visitas y actos festivos previstos para las delegaciones extranjeras (Centenario del Congreso,

${ }^{26}$ Despacho del Cónsul de España en Panamá. Mayo de 1916. Sección del Ministerio de Relaciones Exteriores. Leg. H 3219. AHnE, Madrid, España. 
1925). De ahí que resulte importante analizar en dicho aniversario los usos de la memoria y de los dispositivos simbólicos en su doble funcionalidad: como instrumentos de diplomacia cultural y como vectores de construcción nacional (Chirú Barrios, 2011, pp. 127-139; Marcilhacy, 2018).

Si bien -como ya se verá- en lo relativo a la política interior el Centenario del Congreso de Bolívar no hizo sino recalcar el divorcio social que plagaba aquella república oligárquica, a nivel diplomático dicho certamen se revistió de mayor éxito. Su acto central -el Congreso conmemorativo-reunió a unas 60 delegaciones, con 22 países representados procedentes de América y Europa. Además de las representaciones de 19 naciones americanas, Estados Unidos incluido (tan sólo Costa Rica y Paraguay no estuvieron), participaron oficialmente tres países europeos: Inglaterra y Países Bajos -cuyos comisionados habían sido invitados al Congreso de 1826-, pero también España, en calidad de invitada de honor y como señal de una nueva etapa de las relaciones con la llamada "madre Patria", 100 años después de finalizar las guerras de independencia. A esas embajadas se sumaron unas 45 delegaciones científicas y universitarias, procedentes de nueve países, aunque el grueso vino de Estados Unidos. ${ }^{27}$ Ese logro en términos de participación se debió a una coyuntura internacional sin duda más propicia que en 1916, y también a la implicación de una serie de actores de primer plano en la escena cultural, intelectual y política de Panamá. De hecho, quienes habían auspiciado la conmemoración e integraron la comisión organizadora eran destacados miembros de la elite en el poder, todos con sólida formación y procedentes de los dos principales partidos que habían copado el poder desde la independencia: su presidente era Octavio Méndez Pereira, pedagogo formado en Chile, miembro del Partido Liberal y a la sazón secretario de Instrucción Pública. Le rodeaban Samuel Lewis, doctor en Derecho, miembro destacado del Partido Conservador y ex Secretario de Relaciones Exteriores, y el abogado Fabián Velarde, otra figura del liberalismo, que se había formado en el prestigioso Instituto Nacional.

Los objetivos perseguidos con dicha conmemoración retomaban en parte la función que se le había querido asignar a la exposición de 1916. En palabras del historiador Félix Chirú Barrios (2011, p. 128), la conmemoración de 1926 significó para Panamá tres cosas: demostrar a Latinoamérica su capacidad de mantener la independencia, muy vilipendiada en la región, así como el progreso alcanzado desde 1903; reforzar por otro lado sus vínculos

\footnotetext{
${ }^{27}$ La lista completa figura en Congreso Pan-Americano (1927, pp. 73-79).
} 
"hispanos" con el resto de las naciones del continente; y por fin, insistir en las ventajas de su valiosa posición geográfica, tal como lo había profetizado Bolívar. Aunque todos los delegados coincidieron en reconocer los progresos realizados por Panamá en materia de infraestructuras o de educación, se airearon no pocas disensiones en cuanto a su viabilidad como Estado soberano, dada la imposibilidad de ocultar la dependencia hacia el protector americano, en un contexto de máxima tensión en un plano interior.

A nivel de diplomacia cultural, el centenario fue la ocasión de un verdadero despliegue comunicativo (Marcilhacy, 2018, pp. 97 y ss.). Las múltiples actividades que acompañaron el Congreso propiamente dicho informan sobre la estrategia seguida para hacer resaltar el potencial del país. El programa de visitas propuesto a las delegaciones extranjeras, en particular, resulta significativo. Combinó unas visitas históricas que ponderaban los orígenes coloniales de Panamá -citemos las ruinas de Panamá la Vieja, convertidas en patrimonio público por ley del 19 de octubre de 1912 (Sosa, 1919)-, y otras que recordaban el papel del istmo en el momento de las independencias hispanoamericanas -el programa incluía una sesión solemne en la sala capitular del convento donde Bolívar había reunido el Congreso de 1826.

Pero el programa no sólo pretendía valorar el pasado y la riqueza de su legado, sino que ambicionaba manifestar que Panamá ya había entrado en el camino de las naciones desarrolladas y civilizadas: comprendía también visitas a los modernos centros y establecimientos de sanidad y educación, que daban un reflejo de los avances registrados en el istmo en materia de desarrollo intelectual y científico. Algunos hitos de este recorrido fueron las visitas de las escuelas normales y escuelas profesionales, reflejo de los continuos esfuerzos del gobierno en materia de instrucción pública, así como del hospital recién estrenado Santo Tomás, reputado el "más moderno, mejor equipado y más capaz de la América Latina". ${ }^{28}$ Los delegados eran invitados a observar los progresos de la ciudad en materia de higiene, saneamiento y equipamiento como el alumbrado o la pavimentación. La inauguración de parques y monumentos en la céntrica plaza de Bolívar, a pocas cuadras del Palacio presidencial, entraba en un proyecto destinado a embellecer la ciudad, para darle el estatus y el prestigio de una capital. Obviamente, ese programa no se limitó a la ciudad de Panamá e incluyó visitas a la Zona del Canal -territorio directamente administrado por Estados Unidos- $y$ a sus instalaciones (puer-

28 “Mensaje presidencial de Rodolfo Chiari”, Diario de Panamá, 1-7 de septiembre de 1926. 
to de Balboa, esclusas de Miraflores...). Con semejante recorrido, la idea de los panameños era apoyarse en la experiencia vivida in situ por los delegados extranjeros para contrarrestar la idea difundida de que la Zona constituía un remanso de civilización aislado en un territorio dominado por la incultura y una naturaleza salvaje (Lasso, 2015; Marcilhacy, 2018, pp. 113-124; Missal, 2008, pp. 122-163). Evidentemente este programa descansó en la ocultación voluntaria de los muchos fallos existentes en la tarea modernizadora, como eran el estado de abandono de las provincias interiores, el persistente analfabetismo o la miseria en que malvivía una gran parte de la población, tanto en el interior como en las ciudades terminales de Colón y Panamá.

Esto nos remite a otra dimensión del centenario, o sea su carácter de propaganda comercial, dirigida a seducir a potenciales inversionistas. Para ello, además de las referidas visitas, conviene señalar la publicación de folletos y guías, redactados en varios idiomas, destinados a los viajeros y negociantes extranjeros. Esos libros, a semejanza del Libro Azul de 1917, proporcionaban información sobre el comercio, la salud, las producciones, los lugares de interés, así como notas biográficas de las personalidades más relevantes de la sociedad panameña y del cuerpo diplomático acreditado en la República, según comenta Patricia Pizzurno (2007). Contenían pues una información práctica susceptible de atraer a los capitalistas extranjeros y de acompañarles en sus trámites y negocios en el istmo, siguiendo el modelo del Who's who in America publicado desde 1899 por la Worldwide Branding. Uno de ellos es el Libro de oro. Golden book. Panamá, de Mia Strasser de Saavedra y David Saavedra (1926): esa guía, redactada en inglés, español y alemán, era un estudio comparativo de los beneficios que ofrecía la República de Panamá en comparación con Canadá, Australia, Sudáfrica, Argentina y Brasil, para la realización de inversiones en el sector agropecuario.

Ese despliegue propagandístico no sólo se dirigía a inversionistas e inmigrantes, sino que también pretendía desarrollar el turismo, tanto desde fuera (sobre todo Estados Unidos), como desde la Zona del Canal, que abrigaba a unos 37000 habitantes, la mayoría con una capacidad adquisitiva muy superior a la media nacional. Desde que retomaron la construcción del Canal (1904-1914), los estadunidenses habían iniciado una campaña de promoción sobre Panamá para justificar la ingente inversión de dinero que requería la obra del canal. Así empezaron a publicarse múltiples libros, guías y folletos ilustrados, a menudo en inglés. La afluencia de turistas en los últimos años de la obra llegó a alcanzar la cifra de 20000 al año, atraídos por los encantos de 
ese trópico ya saneado y civilizado y, al mismo tiempo, por descubrir cómo la maquinaria moderna podía cavar las entrañas de esa selva tropical montañosa, como en el Corte Culebra.

Sin lugar a dudas estas campañas pretendían valorar las potencialidades del país para atraer inversiones, turismo y mano de obra cualificada. Y una forma de lograrlo era "vender" a la opinión internacional una imagen del país adaptada a sus expectativas, aunque supusiera abundar en los estereotipos del exotismo prestados a los países de la América Central y el Caribe. Desde mediados del siglo XIX con la construcción y explotación del ferrocarril transístmico (McGuinness, 2009), la impregnación de la sociedad panameña por la cultura estadunidense era profunda y esta se reforzó significativamente a partir de 1903. El propio imaginario estadunidense influyó en la representación de la cultura nacional panameña. Un objeto de consumo que en la época obtuvo un enorme éxito así se convirtió en poco tiempo en el símbolo de la vestimenta nacional, mucho más que la tradicional pollera: se trata del famoso Panama hat, sombrero de paja toquilla que utilizaban los trabajadores del canal en la época de construcción, pero que en realidad se produce en Ecuador (el jipijapa). Fue durante la visita del presidente Roosevelt a las obras del canal en 1906 cuando el pintoresco sombrero se hizo muy popular en todo el mundo, llegando a conocerse desde entonces con ese nombre: la imagen muy estudiada del presidente encaramado en una grúa llevando el famoso sombrero, como si fuera un obrero más, recorrió las portadas de los grandes periódicos internacionales. ${ }^{29}$

El hecho de que se le atribuyera el nombre de "sombrero Panamá" remite a la imagen de marca que se atribuía al país, como arquetipo del trópico cálido, a la vez exótico y civilizado, exuberante y domesticado. La idea era dejar atrás la imagen de un trópico hostil, pantanoso e inhóspito, infectado por insectos y depredadores, donde murieron decenas de miles de trabajadores inmigrantes, antillanos, chinos e indios (hasta que se descubriera el agente infeccioso de la fiebre amarilla en 1903). El Panama hat y la imagen de Teddy Roosevelt en la zanja del canal simbolizaban la promesa de un país conducido en la senda del progreso por la mano de la potencia estadunidense y que al mismo tiempo conservaba su exotismo y su cálido ambiente. Sin duda en la década de 1920 había evolucionado la imagen de Panamá y ya no era un lugar que concentrara tantas fantasías, como a principios de siglo, cuando era

${ }^{29}$ Fotografía titulada "President Theodore Roosevelt siting on a steam shovel at the Panama Canal”. The New York Times, 15 de noviembre de 1906. 
sinónimo de corrupción y escándalo, o se veía como tierra de oportunidades para emigrantes con las obras del canal, o aun como lugar de perdición por su clima, sus pésimas condiciones sanitarias y su moralidad dudosa. Sin embargo, su relativo aislamiento respecto del conjunto latinoamericano, favorecía la difusión de una imagen devaluada o caricaturesca.

De ahí que el centenario de 1926 entrara de lleno en lo que hoy se conoce como la Public Diplomacy, consistente en dirigirse a las opiniones públicas extranjeras para generar comprensión mutua y ganar influencia. Los numerosos delegados invitados, en su gran mayoría diplomáticos, juristas, académicos y periodistas, pueden considerarse como líderes de opinión en sus respectivos países. Los organizadores de los festejos panameños eran muy conscientes del papel de agentes de propaganda que podrían desempeñar a su regreso. Se lo pidió expresamente el presidente del congreso, Octavio Méndez Pereira, en el discurso de clausura del congreso conmemorativo, al despedirse de las delegaciones, el 25 de junio:

Os deseábamos aquí para este género de inspiración, señores delegados, [...] para que auscultarais el corazón de nuestro pueblo y pudierais comprobar lo que heredó de sus abuelos y lo que ha hecho él mismo en los combates del progreso y de la educación. Para que al volver a vuestras patrias podáis decir a los familiares y amigos, que ninguno de vosotros se ha sentido extranjero bajo nuestro techo y que en nuestra tierra de verdura y de sol ningún corazón americano puede sentir la nostalgia de su bandera; para que podáis contar a vuestros hombres de estado cómo piensan y qué anhelan nuestros dirigentes, lo que somos y lo que aspiramos a ser dentro de la agrupación hispánica (Congreso Pan-Americano, 1927, p. 370).

Al final, el conjunto de iniciativas que se adoptaron para preparar y acompañar los festejos del año 1926 tenía como fin dar a conocer al mundo el Panamá contemporáneo, un país liberal, avanzado, abierto y lleno de oportunidades. ${ }^{30}$ Así el centenario sirvió de vitrina del Panamá republicano, en la que se exhibían sus más preciadas joyas, pero que también disimulaba la trastienda más oscura del desarrollo nacional. De hecho, las autoridades y los organizadores del Congreso tuvieron a bien tapar a ojos de los partici-

${ }^{30}$ Véase, por ejemplo, el discurso de clausura dado por el delegado por la Asociación Nacional de Maestros de Panamá, Guillermo Andreve (Congreso Pan-Americano, 1927, p. 216). 
pantes los graves problemas sociales que agitaban al país y que desde el año 1925 se habían convertido en crisis de Estado (Pizzurno, 2011, pp. 141 y ss.). Desde la conclusión de las obras del canal en 1914 y la depresión económica consecutiva a la primera guerra mundial, ${ }^{31}$ la situación social panameña se había convertido en un hervidero que fue degradándose año tras año. Las ciudades de Panamá y de Colón concentraban a una gran masa variopinta de trabajadores recién inmigrados entre quienes muchos se encontraban ya desempleados y abandonados a su suerte (Reid Ellis, 2003, pp. 222 y ss.). La presencia estadunidense era otro motivo de queja constante: tanto los zoneítas (habitantes de la Zona) como los estadunidenses de paso eran percibidos como soberbios y arrogantes, y frecuentes eran los conflictos con la población local, que se sentía paria en su propia tierra. Además del sistema de los comisariatos de la Zona y de la tarifa Dingley, que suponían graves pérdidas para la economía nacional y la Hacienda pública, otro agravio era el control que en la práctica tenían los estadunidenses sobre numerosos sectores, ya que sus técnicos dirigían muchas instituciones educativas, económicas, sanitarias u obras públicas en detrimento de los profesionales nacionales (Pérez y León Lerma, s. a., p. 9).

La precaria situación social se agravó en el año 1925 cuando, a raíz de una ley que reformaba la fiscalidad sobre fincas rústicas, ${ }^{32}$ los caseros pretendieron subir los alquileres. Esta medida afectó principalmente los barrios populares de Santa Ana y el Chorrillo, donde se arrendaban a las masas de trabajadores las numerosas casas de inquilinato, unas viviendas exiguas y promiscuas que generaban a las familias propietarias unos jugosos beneficios. La repentina inflación desató en octubre de 1925 el movimiento inquilinario, una protesta de las masas obreras que adquirió un carácter insurreccional e hizo tambalear el poder de las elites liberales (Gandásegui, 1990, pp. 56 y ss.). Bajo la impulsión del recién nacido Sindicato General de Trabajadores, se creó una Liga de Inquilinos y Subsistencia, que decretó una huelga del alquiler, y recibió el apoyo de muchos inmigrantes de tendencia socialista y anarquista. A esa revuelta se sumó el naciente movimiento nacionalista Acción Comunal, que agrupaba a las clases medias preocupadas por la corrupción y el entre-

${ }^{31}$ Los años 1915-1921 corresponden a un ciclo depresivo de la economía panameña. La recuperación del PIB empezó en 1922 pero fue muy lenta (Kalmanovitz, 2015).

${ }_{32}$ Ley 29 del 11 de febrero de 1925. Gaceta Oficial de Panamá, 25 de febrero de 1925. 
guismo de las elites gobernantes, dispuestas a vender los intereses nacionales a Estados Unidos a cambio de prebendas personales.

La gravedad de la situación condujo a las autoridades a adoptar una medida extrema, que traducía su incapacidad para mantener la cohesión social y el orden público: el gobierno de Rodolfo Chiari requirió la intervención del ejército estadunidense basado en la Zona, que el 12 de octubre penetró en el territorio panameño y se encargó de reprimir con extrema violencia la movilización popular. Esta grave crisis, que revelaba las debilidades del desarrollo panameño y del pacto nacional en el que descansaban sus instituciones, reflejaba una forma de divorcio entre las elites por lado y parte de las clases medias y las masas empobrecidas por otro. ${ }^{33}$ En peor condición de marginación aún se encontraban los indígenas autóctonos kuna, quienes en febrero y marzo del mismo año habían protagonizado en la región periférica de San Blas una auténtica revolución secesionista contra el poder central, por considerar vulnerados sus derechos y costumbres. ${ }^{34}$ Aunque en su conjunto muy mayoritarios en el país, unos y otros se encontraban no sólo segregados espacialmente, sino también excluidos del modelo de nación proyectado por las elites y escenificado en aquellos centenarios. La actitud abandonista del gobierno Chiari, cuyos ministros pocos meses después hablarían en palabras encomiásticas de la libertad y los progresos alcanzados por el país, reflejaba el temor de las elites a una revolución social, para lo cual la protección del ejército estadunidense estaba más que bienvenida.

Proyectada en el año de 1925, toda la organización del aniversario de 1926 tendió a borrar cualquier huella de estas graves divisiones y a ofrecer una imagen armoniosa del cuerpo social, acorde con las ideas de progreso, liberalismo y modernidad que las elites querían proyectar. La idea era también recuperar la iniciativa ofreciendo un discurso de vibrante nacionalismo, en un momento en que la hegemonía cultural de la elite liberal estaba ya reñida por contradiscursos de carácter obrero e internacionalista, o de carácter nacionalista con Acción Comunal.

33 Véase la carta que dirige el secretario de Relaciones Exteriores, Horacio F. Alfaro, a su hermano Ricardo J. Alfaro, ministro de Panamá en Washington, 21 de octubre de 1925. Serie 2, caja 4, carpeta 1, leg. 2.4.C1.1, pp. 59-63. Archivo Biblioteca Ricardo J. Alfaro (en adelante ABRJA), Panamá.

34 En dicha revolución se proclamó la “República de Tule” (Kam Ríos, 1999). 


\section{EL CONGRESO DE 1926 Y LA RESURRECCIÓN DEL IMAGINARIO BOLIVARIANO SOBRE PANAMÁ: MITIFICACIÓN Y CONSTRUCCIÓN NACIONAL}

El centenario así apareció a sus promotores como una oportunidad para elaborar un discurso sobre la nación y contribuir a la tarea de nacionalización de las masas ofreciendo una lectura halagüeña del pasado y de la trayectoria histórica del país. La idea de las elites políticas, educativas y culturales que se implicaron en estos actos, pertenecientes todas a la burguesía liberal, era combatir lo que identificaban como leyendas sobre una nación artificial sin más identidad que la construida por Estados Unidos. Para ello convenía situarla en una continuidad histórica, asumiendo una triple herencia: 1) la obra civilizadora de la colonización española -simbolizada por la figura tutelar de Vasco Núñez de Balboa y la impronta de Pedrarias Dávila-; 2) las revoluciones libertadoras americanas y la labor a favor de la unión continental -auspiciada por el genio de Simón Bolívar-, y 3) el universalismo decimonónico conducente a realizar el sueño de la unión interoceánica -impulsado por el visionario ingeniero francés Ferdinand de Lesseps-. Incurriendo en un proceso de memoria selectiva, este relato insistía en tres legados que les convenía reclamar a las elites cosmopolitas en el poder, y dejaba de lado otras páginas no menos importantes de la historia del istmo, el pasado prehispánico y la unión con Colombia en particular. ${ }^{35} \mathrm{Si}$ bien la celebración del IV Centenario del Descubrimiento del Pacífico había permitido levantar frente a la entrada del canal interoceánico un monumento a Núñez de Balboa (inaugurado en 1924) y otro en recuerdo a los constructores franceses del canal (inaugurado en 1923), el centenario de 1926 sirvió para resaltar otra raíz no menos importante en la formación de la nacionalidad panameña, el legado de Simón Bolívar (Marcilhacy, 2018, cap. 3). ${ }^{36}$

Para Panamá, no se trataba de homenajear al héroe militar sino al genio visionario del Bolívar estadista, que vio en el istmo centroamericano el lugar

\footnotetext{
${ }^{35}$ Aunque el Ayuntamiento de Panamá celebró el primer centenario de la independencia del istmo en 1921, hubo que esperar a 1928 para que se erigiera un monumento al General Tomás Herrera, prócer neogranadino de la separación de España. En cuanto a la raíz indígena, unos actores procedentes de las clases medias promovieron la erección de una más modesta estatua del cacique Urracá, en 1928, la cual posteriormente desapareció de su emplazamiento original.

${ }^{36}$ Sobre la valoración de Bolívar en los discursos oficialistas del centenario bolivariano, véase, por ejemplo, la edición extraordinaria que publicó La Estrella de Panamá el 20 de junio de 1926.
} 
predestinado para realizar su utopía americana de unión, paz y concordia de las repúblicas recién emancipadas, al convocar allí el histórico Congreso Anfictiónico de $1826 .{ }^{37}$ Esta fue la idea que quedó representada en el conjunto monumental que fue inaugurado el 22 de junio de 1926 en la céntrica Plaza de San Francisco, rebautizada Plaza Bolívar. Costeado por las naciones de América (según acuerdo de la V Conferencia Panamericana de Santiago de Chile, 1923), ${ }^{38}$ el monumento debía homenajear al Bolívar estadista y pensador más que al Bolívar capitán de ejércitos. En Panamá el Libertador quedó consagrado como padre de 20 patrias, defensor de la libertad del continente e inspirador de su unidad. Por eso la composición arquitectónica situaba en lo alto un masivo cóndor, ${ }^{39}$ emblema de la América del Sur, velando sobre una de las escasas representaciones de Bolívar vestido de paisano, rodeado de dos figuras alegóricas de la Libertad y de la Paz: de este modo el monumento celebraba su condición de hombre civil y de organizador de naciones. La obra no sólo tuvo un marcado carácter americanista, sino también un carácter hispanista asumido, a juzgar por los discursos que se leyeron y por la autoría del monumento: a pesar de las dificultades que suponía encargar un monumento desde Europa en tan pocos meses, el gobierno panameño escogió al renombrado escultor español Mariano Benlliure, ya autor del monumento al General San Martín de Lima y del dedicado a Nuñez de Balboa en Panamá.

Más allá de la figura de Bolívar, convertido de cierto modo en padre putativo de la patria panameña, ${ }^{40}$ los promotores del centenario pretendieron celebrar la memoria del proyecto bolivariano y subrayar su estrecha vinculación con Panamá. El Congreso conmemorativo en sí tuvo lugar entre el 19 y el 25 de junio de 1926. Los organizadores invitaron a delegaciones de todos los países que en el mismo lugar se habían reunido un siglo atrás, aunque también se invitó a que España participara, como prueba de las buenas relaciones y de la importancia del legado español en la identidad nacional. La Ley de 1925 que convocaba al Congreso establecía las secciones que compondrían dicha asamblea y los distintos temas que se abordarían. La sección primera era de historia, dedicada a recordar la génesis e historia del Congreso de Bo-

\footnotetext{
37 Sobre la dimensión latinoamericanista del Congreso de 1826, véase Granados y Marichal (2004, pp. 39-69).

${ }^{38}$ Quinta Conferencia Internacional Americana (1923), resolución núm. 47.

39 Congreso Pan-Americano, 1927, p. 281.

${ }^{40}$ Véase, por ejemplo, "Homenaje de El Pueblo al padre de la patria y a los delegados al Congreso bolivariano”, El Pueblo, 23 de junio de 1926, p. 1, Panamá.
} 
lívar. Aunque de contenido histórico, también incluía una proyección más contemporánea, al plantear la posibilidad de crear una liga de las naciones americanas inspirada en las ideas del Libertador y en el precedente ginebrino de la Sociedad de las Naciones. Otras secciones se concibieron desde una óptica bastante consensual, como la sección de Instrucción Pública, tendente a debatir la creación en Panamá de centros panamericanos de carácter científico y universitario: el Instituto Gorgas de Medicina Tropical, que efectivamente vio la luz con el Congreso, y la Universidad Panamericana Bolivariana (Méndez Pereira, 1926), que llegó a inaugurarse pero que finalmente no prosperó por falta de presupuesto. ${ }^{41}$ Lo mismo puede decirse de la cuarta sección, "De idiomas" -siendo su objetivo el aprendizaje de las lenguas principales del continente americano y la difusión en los centros docentes de las obras literarias y científicas americanas de más importancia-, o de la quinta, bautizada "De higiene y comercio", que ambicionaba estudiar la influencia del Canal de Panamá en el desarrollo comercial, sanitario y científico de América. Nuevamente, se trataba de resaltar lo atractivo del país como punto de conexión marítima, como zona por donde transitaba el comercio mundial de mercancías, y que, por la posición geoestratégica excepcional que disfrutaba, recibía las influencias enriquecedoras de grandes naciones científicas que, como Estados Unidos, eran punteras en cuanto a medicina y tecnología.

A pesar de ser oficialmente un acto puramente conmemorativo, condición impuesta por el gobierno estadunidense para participar, la dimensión política del Congreso se expresó en todos momentos. La sección tercera tenía un carácter jurídico y pretendía estudiar la influencia del Congreso de 1826 en el desarrollo del derecho internacional y del panamericanismo. En un contexto continental marcado por la hegemonía estadunidense y en el que el panamericanismo washingtoniano generaba cada vez más críticas, fue uno de los temas más reñidos y los debates al respecto tendieron a politizarse, ocasionando el profundo malestar de la delegación estadunidense. ${ }^{42}$ De hecho, los debates tendieron a replantear el proyecto mismo del panamericanismo. Significativamente, la ley de convocatoria de 1925 había bautizado la magna reunión como "Congreso Panamericano" conmemorativo del de Bolívar, con-

${ }^{41}$ Sería el antecedente inmediato de la Universidad Nacional de Panamá, creada en 1935.

${ }^{42}$ Efforts by the United States to prevent the injection of political questions into the proceedings of the Bolívar Congress at Panama. Papers relating to the foreign relations of the United States, 1926, vol. 1, pp. 254-259. 
siderando al Congreso Anfictiónico de 1826 como "la génesis de las posteriores conferencias panamericanas" y reivindicando de esta manera para Bolívar y Panamá la paternidad del proyecto panamericano. ${ }^{43}$ De hecho, las discusiones se orientaron hacia la oposición entre dos panamericanismos, uno que habría sido inspirado por Bolívar -supuestamente equilibrado y respetuoso de las prerrogativas de cada Estado-, y otro más reciente auspiciado por Estados Unidos -que varios delegados no dudaron en calificar como unilateral y depredador y que sería una deformación de la doctrina de Monroe. Varias resoluciones fueron sometidas a la discusión para avanzar en este reequilibrio de las relaciones interamericanas, aunque no dieran resultado práctico: así por ejemplo la que recomendaba crear una Liga Americana de las Naciones, a semejanza del órgano existente en Ginebra, pero cuya creación hubiera podido dar al traste con la Unión Panamericana, foco de muchas críticas. Y es que el choque de doctrinas entre "bolivarismo" y "monroísmo" empezaba a estructurar la literatura de la época relativa a las relaciones interamericanas y al llamado "antiimperialismo", y puede considerarse el Congreso de 1926 como un momento importante para la maduración de este ideario. ${ }^{44}$

Sin poder extendernos aquí sobre el conjunto de los debates y de los temas abordados, se insistirá aquí en la imagen proyectada sobre Panamá y su papel internacional. El centenario y el Congreso conmemorativo sirvieron para producir un discurso que convocó a la figura de Bolívar y que reactualizó su visión sobre el futuro del istmo de Panamá. Varios fueron los ponentes quienes aludieron a su famosa Carta de Jamaica (1815), donde el Libertador había profetizado el destino de este territorio, situado entre dos subcontinentes y dos océanos:

Los estados del istmo de Panamá hasta Guatemala formarán quizá una asociación. Esta magnífica posición entre los dos grandes mares podrá ser con el tiempo el emporio del universo; sus canales acortarán las distancias del mundo; estrecharán los lazos comerciales de Europa, América y Asia; traerán a tan feliz región los tributos de las cuatro partes del globo. ¡Acaso solo allí podrá fijarse algún día la capital de la tierra, como pretendió Constantino que fuese Bizancio la del antiguo hemisferio! (Bolívar, 2004, p. 25).

${ }_{43}$ Ley 5 de 1925. Gaceta Oficial de Panamá, 20 de enero de 1925, p.1.

${ }_{44}$ Daría lugar posteriormente al famoso ensayo de Vasconcelos, Bolivarismo y Monroísmo (1934). 
Los panameños resucitaron la visión bolivariana de un istmo predestinado por su geografía a ser el eje integrador del continente y una ventana abierta al comercio del mundo. Esta vocación de nexo mundial, cuyos orígenes se remontaban a la época colonial y que quedaba simbolizada en el escudo nacional, constituyó un leitmotiv de los discursos, en particular de los delegados panameños. Esta idea figura, por ejemplo, en el mensaje de bienvenida dado por el presidente del Congreso, Octavio Méndez Pereira:

Sed, en buena hora, bienvenidos señores delegados a esta tierra nueva llena de todos los calores y todos los gérmenes, donde cuajan pronto los idealismos y los propósitos nobles, las tolerancias y las palpitaciones de libertad; sed bienvenidos a esta tierra de Balboa y de Pedrarias, que supo blasonar su escudo con un lema del más elevado altruismo, que sabe colocar, por encima de la natural devoción al símbolo de la soberanía nacional, el amor al continente americano, del cual es centro convergente y lazo de unión y ha de ser, sin duda, punto de equilibrio social y político de sus pueblos (Congreso Pan-Americano, 1927, p. 109).

Méndez Pereira recordaba a los delegados esa imagen de un país determinado por su geografía a ser un puente que uniera al continente americano. Recuperaba otro tópico sobre Panamá como una tierra nueva, exuberante y generosa, llena de promesas, que convenía sustituir a la imagen decimonónica de una selva inhóspita plagada de malaria y fiebre amarilla. La bienvenida del ministro de Instrucción Pública también se refería a la divisa nacional, Pro Mundi Beneficio, que traduce la singular construcción nacional de Panamá, un país nacido para servir al mundo.

Así la identidad nacional defendida por la elite liberal en el poder era la de un país universalista, punto de encuentro de razas y civilizaciones, donde era posible su fusión armoniosa gracias al progreso y la prosperidad traídos por el canal. Una idea que ya había desarrollado el gran pedagogo a la hora de invitar a los delegados americanos: "Colocado Panamá en el centro del universo, es el lugar más indicado para que en él se abracen y compenetren las razas que pueblan nuestro continente y para que de él partan, y se difundan así, por todos los ámbitos del mundo, las nuevas ideas y los nuevos ideales de redención" (Congreso Pan-Americano, 1927, p. 15). Vemos aquí la expresión de Panamá como crisol de pueblos y de razas, la afirmación de un afortunado cosmopolitismo en consonancia con la historia de este territorio hecho 
de migraciones múltiples. En realidad, para esa elite europeizada imbuida de racismo, las únicas "razas" a las que pretendían valorar eran la latina y la anglosajona, siendo una constante de los sucesivos gobiernos republicanos el tratar de "blanquear" la raza con la aportación de una inmigración europea y las tentativas de devolver a sus islas a los ex trabajadores antillanos del canal (Pizzurno, 2016, pp. 134-147).

No cabe duda de que el centenario fue un momento intenso en producción de discursos sobre la nación que, si bien iban dirigidos a delegaciones extranjeras, también circulaban en la prensa panameña y ofrecían un discurso positivo y cohesionador sobre la joven nación. Aunque fueron diseñados como acto diplomático, los actos y festejos del centenario incluyeron una dimensión más divulgativa, al incluir eventos deportivos, como exhibiciones de natación, carreras en el hipódromo o ejercicios atléticos, y fiestas populares como conciertos de bandas y fuegos artificiales. La comisión organizadora asimismo había obtenido que los tres días centrales del centenario fueran decretados días cívicos, para implicar a la población en la conmemoración. De este modo la burguesía liberal panameña pretendió oponer un discurso legitimador para su acción en el poder contra la prédica nacionalista y tachada de populista que estaba ofreciendo el recién creado movimiento Acción Comunal.

Si bien coincidían ambas corrientes en la valoración del legado bolivariano como mensaje de confraternidad que colocaba a Panamá en el centro del proceso de solidaridad continental, el año 1926 hizo manifiesta su divergencia en cuanto a la actitud que convenía mantener ante Estados Unidos.

\section{LOS FESTEJOS DE 1926, ¿INSTRUMENTO DE LA DIPLOMACIA PANAMEÑA PARA ADQUIRIR FUERZA EN SU PULSO CON ESTADOS UNIDOS?}

Recordemos que el centenario fue organizado por las autoridades panameñas mientras estaban sumidas en un proceso arduo de renegociación del Tratado del Canal de 1903, para obtener de Estados Unidos condiciones más satisfactorias para la concesión del canal interoceánico (Alfaro, 1972). La posición panameña era delicada, dado que era este país el que reclamaba estas discusiones. El Convenio Taft, difícilmente negociado a fines de 1904 para regular el comercio en la Zona del Canal, fue abrogado unilateralmente por Estados 
Unidos en 1924, lo cual dejó la economía panameña en una situación delicada. Otro problema eran las numerosas ambigüedades del texto de 1903, apresuradamente negociado por Bunau Varilla, que las autoridades panameñas querían aclarar para evitar que la potencia concesionaria se extralimitara en la interpretación de su contenido. En cuanto a las renuncias en materia de soberanía, habían dado lugar a constantes esfuerzos para renegociar el Tratado de 1903, que quedaron vanos hasta que el presidente Coolidge accedió a abrir nuevas discusiones. Pero los negociadores panameños mandados a Washington se toparon con la inflexibilidad del secretario de Estado Charles Hughes, que en la práctica pretendía apoyarse en esta renegociación para confortar la posición de Estados Unidos en el istmo en caso de guerra. ${ }^{45}$

El centenario tuvo lugar cuando precisamente las negociaciones estaban en su última fase, ya que el nuevo tratado sería concluido un mes después, el 28 de julio de 1926. De ahí que podamos interrogarnos sobre otra finalidad del Congreso conmemorativo. Convendría situarlo dentro de una estrategia de pulso que las autoridades panameñas mantenían con Estados Unidos, para compensar su posición de debilidad en esas discusiones bilaterales. De cierta forma dicha asamblea constituyó una plataforma de Soft power "avant la lettre", un vector de propaganda que tuviera como fin ganarse el apoyo no sólo de las cancillerías extranjeras sino también de los líderes de opinión influyentes en las distintas repúblicas americanas para crear un ambiente favorable a la satisfacción de las demandas panameñas de cara al nuevo tratado. En este sentido, el gobierno panameño consideró el centenario como una herramienta diplomática para acercar la diplomacia estadunidense al punto de vista que los panameños creían dominante en los países latinoamericanos, tendente a restablecer un mayor equilibrio en las relaciones interamericanas y en salvaguardar los principios de soberanía e integridad territorial.

La actitud de los delegados panameños durante el Congreso Bolivariano es bastante reveladora de la ambigua posición que mantuvieron durante los actos del centenario, en el que participaba una misión especial del gobierno estadunidense. El diplomático Ricardo J. Alfaro, que desde 1922 era ministro plenipotenciario panameño en Washington encargado de llevar a cabo las

${ }^{45}$ Los tres negociadores eran Ricardo J. Alfaro, Eduardo Chiari y Eusebio A. Morales. Sobre las dificultades que enfrentaron. Véase "Historia de las negociaciones del Tratado. Muchos incidentes surgieron al ser discutido. Los negociadores pasaron por una larga serie de dificultades", El Tiempo, 16 de diciembre de 1926, pp. 4 y 8. 
negociaciones del nuevo tratado, asumió durante dicho congreso una doble representación: la de la Unión Panamericana, de la cual era subdirector, y la de Panamá, como miembro de su delegación oficial. El conflicto de intereses era evidente, y harto revelador de la incómoda situación de Panamá ante los representantes estadunidenses. La dinámica del Congreso pronto lo reveló. El tema del respeto a la soberanía de los Estados, fuesen débiles o fuertes, estuvo omnipresente en los debates, aunque en ningún momento se hiciera mención explícita del caso panameño. Varias declaraciones y resoluciones se refirieron a los principios de igualdad, no intervención y solidaridad que habían de inspirar a las relaciones interamericanas, como principal legado que convenía recordar del pensamiento de Bolívar. Así podemos interpretar, a título de ejemplo, las palabras del abogado panameño Fabián Velarde, cuyo contenido bien podía leerse en clave panameñista:

La solidaridad entre los pueblos débiles que están en contacto con civilizaciones pujantes, es el único elemento capaz de asegurarles la autonomía de sus vidas. Por eso la concepción política de Bolívar, ajustada desde luego al estado presente de las cosas, tiene aún, a pesar de sus cien años, la fuerza de un ideal a cuyo logro nos impulsa la propia conservación (Congreso Pan-Americano, 1927, pp. 488-489).

Si la nota dominante fue la defensa en términos generales de un derecho internacional apoyado en el multilateralismo y la igualdad entre Estados, la vinculación directa con las negociaciones pendientes entre Panamá y Estados Unidos la hizo un invitado especial. Sin que estuviera previsto en el programa acordado, el jurista ecuatoriano Carlos V. Puig, famoso defensor del sindicalismo en su país, sometió a la comisión organizadora una resolución que ofrecía el apoyo de los delegados allí reunidos para que el nuevo tratado que estaba preparándose entre Estados Unidos y Panamá fuera justo y reflejara los sentimientos de fraternidad panamericana que el Congreso había demostrado:

El Congreso de Bolívar, ACUERDA:

Dejar constancia de que América espera ver en la negociación que Panamá va a celebrar con la nación hermana de los Estados Unidos de Norte América la más hermosa expresión de fraternidad americana; y Hacer votos porque el nuevo Tratado del Canal, que Panamá gestiona, sea ante todo, una demostración del espíritu altruista con que los pueblos fuertes de nuestra América, obtienen la cooperación de los débiles, en la obra de solidaridad humana y de 
armónica convivencia internacional que debe constituir la máxima finalidad de las naciones. Dado, etc. Panamá, Junio 22 de $1926 .{ }^{46}$

Esta intromisión en la negociación bilateral que se estaba realizando en el secreto de las cancillerías de Panamá y Washington no fue del agrado de la presidencia del Congreso, que rechazó someter a votación dicha propuesta, considerándola "improcedente e inoportuna".

De modo general, los delegados panameños tuvieron a bien evitar cualquier roce con la delegación estadunidense, e intervinieron repetidas veces para evitar una politización del Congreso, o para desautorizar a los delegados que hubieran infringido el carácter puramente "conmemorativo" del evento. Esta actitud componedora con Estados Unidos suscitó recelos en la prensa y causó indignación entre los sectores opositores, que acusaron al gobierno de Rodolfo Chiari de estar infeudado a los intereses yanquis. Fue el caso del colectivo Acción Comunal, que condenó a la comisión del Congreso cuando censuró la iniciativa del delegado ecuatoriano. En un artículo publicado a raíz del centenario, la organización disidente expresó que el Congreso había sido teatro de la "abyección" más vergonzante, al sacrificar la delegación panameña los intereses de su país para complacer a los estadunidenses. ${ }^{47}$

Cuando un gran periódico cubano dio a conocer a fines del año el contenido del tratado negociado por Panamá, ${ }^{48}$ Acción Comunal emprendió junto con el Sindicato General de Trabajadores una activa campaña de prensa en contra del nuevo acuerdo, tachándole de lesivo para la soberanía nacional y hasta de peligroso para la integridad de la patria. De hecho, el Tratado Kellogg-Alfaro, firmado tan sólo un mes después de los actos del centenario, estaba muy desequilibrado e incluso entrañaba serios compromisos para la república istmeña: si bien Panamá podía recuperar el pacto económico-comercial del Convenio Taft, el precio de esta concesión era crear una alianza militar perpetua entre Panamá y Estados Unidos que aumentaba aún más su dependencia. El nuevo acuerdo, tildado de "tratado-garrote" por el influyente periodista

${ }^{46}$ Proyecto de resolución reproducido en Acción Comunal, 1928, p. 71. Significativamente, dicha propuesta no figura en las actas oficiales del Congreso Bolivariano.

47 La voz de Acción Comunal en el Congreso Bolivariano de 1926 (Acción Comunal, 1928, pp. 69 y ss.).

${ }_{48}$ Heraldo de Cuba, 5 de diciembre de 1926 (tratado reproducido en Repertorio Americano, diciembre de 1926). 
Diógenes de la Rosa, ${ }^{49}$ se convirtió en la manzana de la discordia de la política panameña y enfrentó posturas durante meses. El pulso con el gobierno se concluyó con una primera victoria del movimiento popular encabezado por Acción Comunal, ya que los diputados panameños finalmente se negaron a ratificarlo y el 25 de enero de 1927 suspendieron las negociaciones con Estados Unidos. Panamá debería esperar la llegada de Franklin D. Roosevelt y la política de la "buena vecindad", para poder obtener un nuevo acuerdo más equilibrado, con la firma del Tratado Arias-Roosevelt en 1936.

\section{CONSIDERACIONES FINALES}

La celebración del centenario de 1926 intervino en un contexto importante tanto para la historia panameña como a escala del continente americano. Se produjo en un momento en que se resquebrajaban las dinámicas que habían regulado las relaciones sociales a nivel nacional y geopolíticas a escala continental. El pretendido pacto social que debía haber legitimado a la elite liberal que dominaba la política panameña desde 1910 ofrecía claras señales de agotamiento a mediados de la década 1920. Proclives a hablar de la liberación de las energías individuales y sociales mediante la educación y el progreso tecnológico y científico, dichas elites quedaron enredadas en las ambigüedades de su proyecto de nación, ante todo concebido por y para la oligarquía comercial y terrateniente que ocupaba el poder. El progresivo divorcio con las clases medias y populares conduciría al golpe de Estado de 1931, auspiciado por Acción Comunal y que llevó al poder al jurista Harmodio Arias Madrid. En el hemisferio, nuevas corrientes del antiimperialismo estaban en pleno desarrollo (Pita González y Marichal, 2012), constituyendo Panamá un caso de estudio típico de esa literatura anti-yankee. En semejante contexto, el panamericanismo promocionado desde Washington entró en crisis en esos años, lo cual sería confirmado por el fracaso relativo de la VI Conferencia Interamericana de La Habana, en 1928.

Si bien el centenario de 1913 permitió inscribir simbólicamente a la nación panameña en la "familia" hispánica, la Exposición Nacional organizada en 1916 no dio los resultados esperados en un plano diplomático. A pesar de la

49 "Diógenes de la Rosa. Un fracaso aleccionador", Repertorio Americano, 14 de agosto de 1926, pp. 84-85. 
relación privilegiada establecida con España - una potencia de segunda fila-, Panamá no consiguió salir de su relación aún muy exclusiva con el protector estadunidense. Por eso, la organización del Centenario del Congreso de Bolívar pareció a las autoridades como una buena oportunidad para corregir la imagen que se tenía de Panamá, una república considerada como artificial, subdesarrollada y abandonada a una tutela humillante. Al mismo tiempo, al intervenir en el momento en que su diplomacia trataba de renegociar el tratado de 1903, el Congreso conmemorativo entró en una tímida estrategia para internacionalizar (o latinoamericanizar) la cuestión del Canal y así evitar un frente a frente asimétrico con Estados Unidos. Pero en este aspecto el gobierno siguió preso de sus contradicciones, como supo argumentarlo la hábil campaña realizada por Acción Comunal.

Finalmente, el mayor logro que obtuvo Panamá con estos aniversarios fue la inscripción de su nacionalidad en una doble filiación: la herencia española, con el Adelantado del Mar del Sur, y la inscripción americana, con el Libertador grancolombiano. La recuperación de Núñez de Balboa y Bolívar, un español y un venezolano, y la construcción de ambas figuras como héroes nacionales contribuyeron a que la joven república panameña definiera su lugar entre las naciones hispanohablantes y en el seno americano, un lugar capitalino como había profetizado en su tiempo Bolívar. Al recurrir a referencias externas, la elite panameña conectó memorias compartidas, una -la de Núñez de Balboa- fundacional para el imperio español y para la primera era de la globalización, y otra -la de Bolívar-central en la emancipación del continente americano. La conversión de esos dos héroes en figuras tutelares de la patria respondió quizá a los nuevos desafíos que la apertura de una vía interoceánica bajo custodia estadunidense planteaba a Panamá. Pero dejó a un lado a toda una franja de la población istmeña que había hecho posible la realización de este destino nacional, los inmigrantes afrocaribeños y los indígenas autóctonos. Asimismo, fracasó a la hora de cambiar de manera perenne la percepción que desde el extranjero se tenía de Panamá, como probaría la violenta campaña mediática que se desató en el extranjero cuando se reveló el contenido del Tratado Kellogg-Alfaro que, por empeorar la situación de dependencia inicial, fue tildado de "Pacto Infame" y que parecía confirmar la presunta "leyenda negra" en contra del joven Estado. 


\section{LISTA DE REFERENCIAS}

Acción Comunal (1928), Panamá, sus problemas y sus hombres. Panamá: Casa Editorial Acción Comunal.

Alfaro, R. J. (1972). Historia documentada de las negociaciones para la celebración del Tratado de 1926. Panamá: Editorial Universitaria.

Araúz, C. A. (1994). Panamá y sus relaciones internacionales. Estudio introductorio, notas y antología. Panamá: EuPAN.

Araúz, C. A. (2004). Estudio historiográfico sobre las interpretaciones en torno a la separación de Panamá de Colombia en 1903. En H. Bonilla y G. Montañez (eds.), Colombia y Panamá. La metamorfosis de la nación en el siglo Xx (pp. 353-378). Bogotá: Universidad Nacional de Colombia.

Araúz, C. A. y Pizzurno, P. (1996). Estudios sobre el Panamá republicano. 1903-1989. Panamá: Manfer.

Bolívar, S. (2004). Páginas escogidas. Caracas: Monte Ávila.

Castillero Calvo, A. (1999). La ruta interoceánica y el Canal de Panamá. Panamá: Universidad de Panamá.

Centenario del Congreso Panamericano de Bolivar. Constitución, Reglamento y Temas (1925). Boletín núm. 2, Panamá: Imprenta Nacional.

Congreso Pan-Americano Conmemorativo del de Bolívar 1826-1926 (1927). Panamá: Imprenta Nacional.

Chirú Barrios, F. J. (2011). Conmemoraciones y monumentalidad: las políticas de la memoria en Panamá, 1903-1931. (Tesis doctoral). Universidad de Costa Rica, San José.

Chirú Barrios, F. J. (2012). Liturgia al héroe nacional: el monumento a Vasco Núñez de Balboa en Panamá. Cuadernos Inter.c.a.mbio, 9(10), 71-99. Recuperado de https://revistas.ucr.ac.cr/index.php/intercambio/article/view/2977

Díaz Ospino, O. (2004). El país creado por Wall Street. La historia prohibida de Panamá y su canal. Barcelona: Destino.

Gandásegui, M. A. et al. (1990). Las luchas obreras en Panamá, 1850-1978. Panamá: Centro de Estudios Latinoamericanos Justo Arosemena.

Granados, A. y Marichal, C. (coords.) (2004). Construcción de las identidades latinoamericanas. Ensayos de historia intelectual, siglos XIX y Xx. México: El Colegio de México.

Kalmanovitz, S. (2015). Capacidad estatal, fiscalidad y subyugación: Panamá entre 1903-1945. Tiempo \& Economía, 2(1), 9-51.

Kam Ríos, J. (1999). La revolución Tule de 1925: La república de los hombres. Revista Cultural Lotería, 424, 37-44. 
Lasso, M. (2015). A Canal without a Zone: Conflicting representations of the Panama Canal. Journal of Latin American Geography, 14(3), 157-174.

McCullough, D. (2012). Un camino entre dos mares. La creación del canal de Panamá. [1977]. Madrid: Espasa.

McGuinness, A. (2009). Path of empire. Panama and the California gold rush. Ithaca-Londres: Cornell University Press.

Marcilhacy, D. (2006). Une histoire culturelle de l'hispano-américanisme (1910-1930): l'Espagne à la reconquête d'un continent perdu. (Tesis doctoral). Université de la Sorbonne Nouvelle, París. Recuperado de https://hal.archives-ouvertes.fr/tel-01879267

Marcilhacy, D. (2010). Raza hispana. Hispanoamericanismo e imaginario nacional en la España de la Restauración. Madrid: CEPC.

Marcilhacy, D. (2018). Panama “panaméricain”. Le centenaire bolivarien de 1926, mémoires croisées et projections transnationales. (Tesis de Habilitación a Dirigir Investigaciones [HDR]). Sorbonne Université, París.

Mena García, C. (2014). Núñez de Balboa, la Mar del Sur y la efeméride de 1913. En F. J. Montero Llácer (coord.), El océano Pacífico: conmemorando 500 años de su descubrimiento (pp. 49-60). Sevilla: Universidad de Sevilla.

Méndez Pereira, O. (1926). La Universidad Americana y la Universidad Bolivariana de Panamá. Panamá: Imprenta Nacional.

Missal, A. (2008). Seaway to the future. American social visions and the construction of the Panama Canal. Madison: The University of Wisconsin Press.

Moreno Luzón, J. (2010). Reconquistar América para regenerar España: nacionalismo español y centenario de las independencias en 1910-1911. Historia Mexicana, 60(1: 237), 561-640.

Moreno Luzón, J. (2017). Herederos de Balboa. España y la construcción de identidades en California y Panamá a comienzos del siglo xx. Anuario Instituto de Estudios Histórico-Sociales, 32(1), 155-178.

Núñez, L. Á. (2004). El rapto de Panamá en la caricatura política, 1903-1930. En H. Bonilla y G. Montañez (eds.), Colombia y Panamá. La metamorfosis de la nación en el siglo Xx (pp. 413-440). Bogotá: Universidad Nacional de Colombia.

Papers relating to the foreign relations of the United States (1926). Washington, DC: US Government Printing Office.

Pérez, V. M., y León Lerma, R. Ó. de (s. f.). El Movimiento de Acción Comunal en Panamá [1964]. Panamá: Editorial El Arte Tipográfico.

Pérez, M. y Nougués, P. (1915). Los precursores españoles del Canal Interoceánico. Madrid: Perlado, Páez y Cía. 
Pérez Vejo, T. (2011). Enemigos íntimos. España, lo español y los españoles en la configuración nacional hispanoamericana 1810-1910. México: El Colegio de México.

Pita González, A. y Marichal, C. (coords.) (2012). Pensar el antiimperialismo. Ensayos de historia intelectual latinoamericana, 1900-1930. México: El Colegio de México.

Pizzurno, P. (2007). El turismo y el patrimonio en el Panamá Republicano: apuntes históricos. Canto Rodado, 2, 1-22.

Pizzurno, P. (2011). Memorias e imaginarios de identidad y raza en Panamá, siglos XIX y xx. Panamá: Editorial Mariano Arosemena.

Pizzurno, P. (2016). El miedo a la modernidad en Panamá (1904-1930). Panamá : Cultural Portobelo.

Quinta Conferencia Internacional Americana. Santiago de Chile (1923). Actas de las Sesiones Plenarias. Santiago de Chile: Imprenta Universitaria.

Reid Ellis, A. (2003). Causes et conséquences économiques, politiques et culturelles de la migration dans l'aire des Caraïbes et de l'Amérique centrale au $\mathrm{xx}^{e}$ siècle. París: Publibook.

Samos, A. (ed.) (2017). Panamá cosmopolita: la Exposición Nacional de 1916 y su legado. Panamá: "Biblioteca 500".

Scoullar, W. T. (1916-1917). El libro azul de Panamá. The blue book of Panama. Panamá: The Latin America Publicity Bureau.

Secretaría de Fomento (1913). Exposición Nacional de Panamá, conmemorativa del Descubrimiento del Mar del Sur, Panamá, Imprenta Nacional.

Sociedad Española de Beneficencia (1913). Recuerdo de la velada literaria conmemorativa del descubrimiento del Mar del Sur en 1513 por el adelantado Vasco Núñez de Balboa, celebrada en el Teatro Nacional bajo los auspicios de la Sociedad Española de Beneficencia, en la noche del 25 de septiembre de 1913. Panamá: Star \& Herald.

Sosa, J. B. (1919). Panamá la Vieja con motivo del cuarto centenario de su fundación, 15191919. Panamá: Imprenta Nacional.

Strasser de Saavedra, M. y Saavedra, D. (1926). Libro de oro. Golden book. Panamá. Panamá: Imprenta Nacional.

Szok, P. A. (2001). La última gaviota. Liberalism and nostalgia in early twintieth-century Panama. Westport-Londres: Greenwood Press.

The Latin American Publicity Bureau (1916). Exposición de Panamá. Panamá: Editorial La Moderna.

Thiesse, A.-M. (2006). Les identités nationales, un paradigme transnational. En A. Dieckhoff y Ch. Jaffrelot (dirs.), Repenser le nationalisme. Théories et pratiques (pp. 193-226). París: Sciences Po. 
United States Congress House (1913). The story of Panama: hearings on the Rainey resolution before the Committee on Foreign Affairs of the House of Representatives. Washington: Government Printing Office.

Vasconcelos, J. (1934). Bolivarismo y Monroísmo: temas iberoamericanos. Santiago de Chile, Ercilla.

\section{OTRAS FUENTES}

\section{Archivos}

AHNE Archivo Histórico Nacional de España, Madrid, España.

Amirep Archivo del Ministerio de Relaciones Exteriores de Panamá, Panamá.

ABRJA Archivo Biblioteca Ricardo J. Alfaro, Panamá.

\section{Periódicos}

$A B C$, Madrid.

Boletín de la Real Sociedad Geográfica, Madrid.

Cultura Hispano-Americana, Madrid.

Diario de Panamá, Panamá.

El Imparcial, Madrid.

El Mundo, Panamá.

El Pueblo, Panamá.

El Tiempo, Panamá.

Gaceta de Madrid, Madrid.

Gaceta Oficial, Panamá.

Heraldo de Cuba, La Habana.

La Estrella de Panamá, Panamá.

Repertorio Americano, San José.

The New York Times, Nueva York.

Unión Ibero-Americana, Madrid. 